\title{
The Influence of Principal Leadership and Competence on Junior High School Teacher Performance in Air Kumbang District
}

\author{
Filly Hardian ${ }^{1 *}$, Happy Fitria ${ }^{2}$, Achmad Wahidy ${ }^{2}$ \\ ${ }^{1}$ Dinas Pendidikan dan Kebudayaan Kabupaten Banyuasin, South of Sumatera, Indonesia \\ ${ }^{2}$ Universitas PGRI Palembang, Indonesia \\ *Corresponding author. Email: fillyhardian@gmail.com
}

\begin{abstract}
The aim of this study was to determine whether principal leadership and competence have an effect on junior high school teacher performance in the Air Kumbang district. The descriptive quantitative approach was used in this study. The correlation coefficient between leadership (X1) and performance (Y) is 0.683 based on the correlation analysis results, suggesting that there is an adequate correlation (correlation) between leadership and performance. As a result, the better the principal's leadership, the better the teacher's performance. While the correlation coefficient between competence $(\mathrm{X} 2)$ and performance $(\mathrm{Y})$ is 0.566 , this indicates that there is enough of a correlation (correlation) between competence and performance. In other words, the better the principal's competence, the better the teacher's results.
\end{abstract}

Keywords: Leadership, Competence, Teacher Performance

\section{INTRODUCTION}

Essentially it can be said that leadership is an effort to achieve common goals of people. As a consequence, leaders must pay attention to the relationship between tasks and people [1]. The role of organizational leadership officials is crucial in achieving previously defined priorities and objectives. This means that leaders are highly coveted by all interested parties in the organization and the ability to make decisions is the main criterion in assessing the effectiveness of one's leadership.

With the existence of Regional Government Law Number 22 of 1999 and Government Regulation Number 25 of 2000 governing the jurisdiction of the Regency / City government as an autonomous region. Some of the roles have been transferred, tasks and authorities that were previously owned by the central or provincial governments is transferred to the district / city governments, even up to the granting of educational autonomy at the school level. In implementing regional autonomy, one form of granting authority in the field of education to schools is school-based quality improvement management. It is hoped that schools will be able to empower, develop and increase their potential. The principal is given proportional authority to process education so that school goals can be achieved effectively and efficiently. The principal is the school's highest official, and his or her leadership style would be very prominent, if not definitive, in the school's success. The principal's way or initiative in shaping, promoting, guiding, directing, mobilizing teachers, staff, students, parents of students, and other relevant parties to work / engage in achieving the specified goals is known as principal leadership. In a nutshell, how the principal "forces" others to cooperate in order to accomplish school goals.

The principal's leadership is situational, meaning that leadership can be effective for certain situations and less effective for other situations. For example: in an emergency situation at school, for example when a fire breaks out, or a student fight, authoritarian leadership is also effective. In contrast, the authoritarian leadership type is less effective for normal situations at school. Thus the principal must be able to understand the situation that occurs in school so that he can apply the type of effective leadership.

The principal's leadership has the ability to influence, motivate, guide, direct, and organize teachers, administrative staff, students, students' parents, and other relevant parties. The principal is a teacher who has been assigned the additional responsibility of leading 
teachers and other school personnel in working together to achieve school goals.

The Minister of National Education Regulation Number 13 of 2007 concerning School Principal Qualifications notes that school principals must be qualified. There are five dimensions of competence in these regulations: personality, administrative, entrepreneurship, supervision, and social. Every competency dimension includes fundamental competencies that a school principal must possess. According to Article 10 paragraph (1) of Law No. 14 of 2005 Concerning Teachers and Lecturers, teacher competence requires pedagogical competence, personality competence, social competence, and technical competence gained through professional education. Mentions competence as skill, which is an individual's ability to perform different tasks in a job [4]. This competency is demonstrated by the ability to plan and carry out teaching and learning activities, conduct interactions or monitor the teaching and learning process, and administer tests. Competency is an individual's underlying trait that is causally related to criterion-reference successful and/or superior performance in a job or circumstance [5].

Teachers as educators whose main task is teaching, have personality characteristics that greatly influence the success of human resource development,

Principals are appointed based on work experience and rank, not based on education and training, this condition tends to result in the principal not mastering the knowledge of management leadership and education administration which is identified as having an effect on teacher performance. The leadership of the principal who is less able to encourage teachers and consultations to perform well, and develop themselves.

The work performance of employees must really be considered. Performance (is the result of work in quality and quantity achieved by an employee in carrying out his duties in accordance with the responsibilities assigned to him [2]. Meanwhile, employee performance depends on ability, work effort and job opportunities which can be assessed from output [3].

\section{METHODS}

This study's aim is to conduct a survey using a mixed system of descriptive-qualitative and quantitative-inferential data. A survey is a type of research technique in which information is gathered using a questionnaire [6].

This study's data source is a secondary data source derived from available documents or records. Primary and secondary data were obtained using a data sampling technique.

The external validity of the questionnaire was evaluated in this study using item analysis methods, specifically knowing the consistency between the item scores and the overall score.

Data analysis is achieved by data transformation in the form of presenting data that is simple to understand and interpret. The average value, frequency distribution, polygon and histogram graphs, pie charts, and pictograms are used to summarize data in descriptive study. group explanation via mode, median, mean, and ranges and standard deviation, and group variance via ranges and standard deviation The SPSS version 18.0 software machine will be used for descriptive analysis.

\section{RESULTS AND DISCUSSION}

\section{1) Normality test}

The significance value of the teacher output variable is 0.151 in the table, 0.93 for the leadership variable, and 0.164 for the competency variable. Each variable's significance value is greater than 0.05 , indicating that $\mathrm{Ha}$ is appropriate or that the data from each of these variables is normally distributed.

Table 1. Tests of Normality

\begin{tabular}{|c|c|c|c|c|c|c|}
\hline & \multicolumn{3}{|c|}{$\begin{array}{l}\text { Kolmogorov- } \\
\text { Smirnova }\end{array}$} & \multicolumn{3}{|c|}{ Shapiro-Wilk } \\
\hline & $\begin{array}{l}\text { Statis } \\
\text { tic }\end{array}$ & Df & Sig. & $\begin{array}{l}\text { Stati } \\
\text { stic }\end{array}$ & $\mathrm{df}$ & Sig. \\
\hline $\begin{array}{l}\text { Performance } \\
\text { (Y) }\end{array}$ & .151 & 74 & .000 & .951 & 74 & .006 \\
\hline $\begin{array}{c}\text { Leadership } \\
\left(\mathrm{X}_{1}\right)\end{array}$ & .093 & 74 & .186 & .961 & 74 & .023 \\
\hline $\begin{array}{c}\text { Competence } \\
\left(\mathrm{X}_{2}\right)\end{array}$ & .164 & 74 & .000 & .917 & 74 & .000 \\
\hline
\end{tabular}

a. Lilliefors Significance Correction

The significance value of the teacher output variable is 0.151 in the table, 0.93 for the leadership variable, and 0.164 for the competency variable. Each variable's significance value is greater than 0.05 , indicating that $\mathrm{Ha}$ is appropriate or that the data from each of these variables is normally distributed. 
Table 2. Linearity Test

\begin{tabular}{|c|c|c|c|c|c|c|c|}
\hline \multicolumn{8}{|c|}{ ANOVA Table } \\
\hline & & & $\begin{array}{l}\text { Sum of } \\
\text { Squares }\end{array}$ & df & $\begin{array}{l}\text { Mean } \\
\text { Square }\end{array}$ & $\mathrm{F}$ & Sig. \\
\hline \multirow{5}{*}{$\begin{array}{l}\text { Performance }(\mathrm{Y}) * \\
\text { Leadership }\left(\mathrm{X}_{1}\right)\end{array}$} & \multirow{3}{*}{$\begin{array}{l}\text { Between } \\
\text { Groups }\end{array}$} & (Combined) & 414.882 & 13 & 31.914 & 7.954 & .000 \\
\hline & & Linearity & 305.989 & 1 & 305.989 & 76.258 & .000 \\
\hline & & $\begin{array}{l}\text { Deviation from } \\
\text { Linearity }\end{array}$ & 108.893 & 12 & 9.074 & 2.262 & .019 \\
\hline & \multicolumn{2}{|c|}{ Within Groups } & 240.753 & 60 & 4.013 & & \\
\hline & \multicolumn{2}{|c|}{ Total } & 655.635 & 73 & & & \\
\hline \multirow{5}{*}{$\begin{array}{l}\text { Performance }(\mathrm{Y}) * \\
\text { Competence }\left(\mathrm{X}_{2}\right)\end{array}$} & \multirow{3}{*}{$\begin{array}{l}\text { Between } \\
\text { Groups }\end{array}$} & (Combined) & 280.671 & 8 & 35.084 & 6.082 & .000 \\
\hline & & Linearity & 210.043 & 1 & 210.043 & 36.411 & .000 \\
\hline & & $\begin{array}{l}\text { Deviation from } \\
\text { Linearity }\end{array}$ & 70.629 & 7 & 10.090 & 1.749 & .113 \\
\hline & \multicolumn{2}{|c|}{ Within Groups } & 374.964 & 65 & 5.769 & & \\
\hline & \multicolumn{2}{|l|}{ Total } & 655.635 & 73 & & & \\
\hline
\end{tabular}

From the results of the data above, the value of Deviation from Linearity / Sig is: Performance (Y) on Leadership $\left(\mathrm{X}_{1}\right)=0.019$ and Performance $(\mathrm{Y})$ on Competence $\left(\mathrm{X}_{2}\right)=0.113$, the variable has an Asymp value. $\mathrm{Sig}>0.05$, so it has a linear relationship.

\section{2) Multicollinearity Test}

Table 3. Multicollinearity Test

\begin{tabular}{|c|c|c|c|c|c|c|c|c|c|}
\hline \multirow[b]{2}{*}{ Model } & \multicolumn{2}{|c|}{$\begin{array}{l}\text { Unstandardi } \\
\text { zed } \\
\text { Coefficients }\end{array}$} & \multirow[b]{2}{*}{$\mathrm{T}$} & \multirow[b]{2}{*}{ Sig } & \multicolumn{3}{|c|}{ Correlations } & \multicolumn{2}{|c|}{$\begin{array}{c}\text { Collinearity } \\
\text { Statistics }\end{array}$} \\
\hline & $\mathrm{B}$ & $\begin{array}{l}\text { Std. } \\
\text { Error }\end{array}$ & & & $\begin{array}{c}\text { Zero } \\
- \\
\text { order }\end{array}$ & $\begin{array}{c}\text { Part } \\
\text { ial }\end{array}$ & Part & $\begin{array}{c}\text { Tolera } \\
\text { nce }\end{array}$ & VIF \\
\hline 1 (Constant) & $\begin{array}{r}12.6 \\
49 \\
\end{array}$ & 6.127 & $\begin{array}{r}2.0 \\
65 \\
\end{array}$ & $\begin{array}{r}.04 \\
3 \\
\end{array}$ & & & & & \\
\hline Leadership $\left(X_{1}\right)$ & .533 & .061 & $\begin{array}{r}8.7 \\
57 \\
\end{array}$ & $\begin{array}{r}.00 \\
0 \\
\end{array}$ & .683 & .721 & .594 & .970 & $\begin{array}{r}1.03 \\
1 \\
\end{array}$ \\
\hline Competence $\left(\mathrm{X}_{2}\right)$ & .544 & .081 & $\begin{array}{r}6.7 \\
00\end{array}$ & $\begin{array}{r}.00 \\
0\end{array}$ & .566 & .622 & .454 & .970 & $\begin{array}{r}1.03 \\
1\end{array}$ \\
\hline
\end{tabular}

a. Dependent Variable: Performance (Y)

\section{3) Multiple Linear Regression Analysis}

The tolerance value for Leadership $\left(\mathrm{X}_{1}\right)$ is 0.970 , and the tolerance value for Competence $\left(\mathrm{X}_{2}\right)$ is 0.970 . All are smaller than 10 so there is no problem.

\section{Table 4. Coefficients}

\begin{tabular}{|c|c|c|c|c|c|c|c|c|c|c|c|c|}
\hline \multirow[b]{2}{*}{ Model } & \multicolumn{2}{|c|}{$\begin{array}{l}\text { Unstandardized } \\
\text { Coefficients }\end{array}$} & \multirow{2}{*}{$\begin{array}{c}\text { Standardized } \\
\text { Coefficients } \\
\text { Beta }\end{array}$} & \multirow[b]{2}{*}{$\mathrm{T}$} & \multirow[b]{2}{*}{ Sig. } & \multicolumn{2}{|c|}{$\begin{array}{c}95,0 \% \\
\text { Confidence } \\
\text { Interval for B }\end{array}$} & \multicolumn{3}{|c|}{ Correlations } & \multicolumn{2}{|c|}{$\begin{array}{l}\text { Collinearity } \\
\text { Statistics }\end{array}$} \\
\hline & B & $\begin{array}{l}\text { Std. } \\
\text { Error }\end{array}$ & & & & $\begin{array}{l}\text { Lower } \\
\text { Bound }\end{array}$ & $\begin{array}{l}\text { Upper } \\
\text { Bound }\end{array}$ & $\begin{array}{l}\text { Zero- } \\
\text { order }\end{array}$ & Partial & Part & Tolerance & VIF \\
\hline 1 (Constant) & 12.649 & 6.127 & & 2.065 & .043 & .433 & 24.866 & & & & & \\
\hline $\begin{array}{l}\text { Leadership } \\
\left(\mathrm{X}_{1}\right)\end{array}$ & .533 & .061 & .603 & 8.757 & .000 & .411 & .654 & .683 & .721 & .594 & .970 & 1.031 \\
\hline $\begin{array}{l}\text { Competence } \\
\left(\mathrm{X}_{2}\right)\end{array}$ & .544 & .081 & .461 & 6.700 & .000 & .382 & .706 & .566 & .622 & .454 & .970 & 1.031 \\
\hline
\end{tabular}

a. Dependent Variable: Performance (Y) 
From the table, the value of the constant (constant) coefficient is $\mathrm{C}=12.649$, while Leadership $\left(\mathrm{X}_{1}\right)$ is a value of $\mathrm{a}=0.533$ and Competence $\left(\mathrm{X}_{2}\right)$ is a value of $\mathrm{b}$ $=0.544$, so that the multiple linear function:
$Y=12,649+0,533 X_{1}+0,544 X_{2}$

4) Analysis of the Determinant Coefficient $\left(R_{2}\right)$.

Table 4. Analysis of the Determinant Coefficient $\left(\mathbf{R}_{2}\right)$

\begin{tabular}{|c|c|c|c|c|c|c|c|c|c|}
\hline \multirow[b]{2}{*}{ Model } & \multicolumn{2}{|c|}{ Unstandardized Coefficients } & \multirow[b]{2}{*}{$\mathrm{T}$} & \multirow[b]{2}{*}{ Sig. } & \multicolumn{3}{|c|}{ Correlations } & \multicolumn{2}{|c|}{ Collinearity Statistics } \\
\hline & $\mathrm{B}$ & Std. Error & & & Zero-order & Partial & Part & Tolerance & VIF \\
\hline 1 (Constant) & 12.649 & 6.127 & 2.065 & .043 & & & & & \\
\hline Leadership $\left(X_{1}\right)$ & .533 & .061 & 8.757 & .000 & .683 & .721 & .594 & .970 & 1.031 \\
\hline Competence $\left(\mathrm{X}_{2}\right)$ & .544 & .081 & 6.700 & .000 & .566 & .622 & .454 & .970 & 1.031 \\
\hline
\end{tabular}

a. Dependent Variable: Performance (Y)

According to the results of the questionnaire data testing, the determinant coefficient $\left(\mathrm{R}_{2}\right)$ was 0.673 , which indicates that the principal's leadership and competence contribute 67.3 percent to teacher success, while the remaining 32.7 percent were affected by other factors or variables. The primary leadership factors and integrity in relation to success have a significant impact. The principal's leadership leads to efforts to increase the principal's performance and competence, as well as to efforts to improve teacher performance.

Table 5. Model Summary

\begin{tabular}{|c|c|c|c|c|c|c|c|c|}
\hline \multirow[b]{2}{*}{ Model } & \multirow[b]{2}{*}{$\mathrm{R}$} & \multirow[b]{2}{*}{$\begin{array}{c}\mathrm{R} \\
\text { Square }\end{array}$} & \multirow[b]{2}{*}{$\begin{array}{l}\text { Adjusted R } \\
\text { Square }\end{array}$} & \multirow[b]{2}{*}{$\begin{array}{l}\text { Std. Error of the } \\
\text { Estimate }\end{array}$} & \multicolumn{4}{|c|}{ Change Statistics } \\
\hline & & & & & $\begin{array}{l}\text { R Square } \\
\text { Change }\end{array}$ & $\begin{array}{c}\mathrm{F} \\
\text { Change }\end{array}$ & df1 df2 & $\begin{array}{c}\text { Sig. F } \\
\text { Change }\end{array}$ \\
\hline 1 & $.821^{\mathrm{a}}$ & .673 & .664 & 1.737 & .673 & 73.153 & 271 & .000 \\
\hline
\end{tabular}

Based on the data presented above, it is clear that the distribution of responses for each variable is very good., this is indicated by the low standard deviation or standard deviation of each variable. For Performance

(Y) standard deviation $=2.997$, leadership $\left(\mathrm{X}_{1}\right)$ standard deviation $=3.393$ and competence $\left(\mathrm{X}_{2}\right)$ standard deviation $=2.540$.

\section{5) Control Correlation Analysis}

Table 6. Correlations

Kinerja (Y) Leadership $\left(\mathrm{X}_{1}\right)$ Competence $\left(\mathrm{X}_{2}\right)$

\begin{tabular}{llcc|c}
\hline Pearson Correlation & Performance $(\mathrm{Y})$ & 1.000 & .683 & .566 \\
\cline { 2 - 5 } & Leadership $\left(\mathrm{X}_{1}\right)$ & .683 & 1.000 & .173 \\
\hline \multirow{2}{*}{ Sig. (1-tailed) } & Competence $\left(\mathrm{X}_{2}\right)$ & .566 & .173 & 1.000 \\
\hline $\mathrm{N}$ & Performance $(\mathrm{Y})$ &. & .000 & .000 \\
\hline & Leadership $\left(\mathrm{X}_{1}\right)$ & .000 &. & .070 \\
\hline & Competence $\left(\mathrm{X}_{2}\right)$ & .000 & .070 &. \\
\hline & Performance $(\mathrm{Y})$ & 74 & 74 & 74 \\
\hline & Leadership $\left(\mathrm{X}_{1}\right)$ & 74 & 74 & 74 \\
\hline & Competence $\left(\mathrm{X}_{2}\right)$ & 74 & 74 & 74 \\
\cline { 2 - 5 } & & & & \\
\hline
\end{tabular}

Based on the results of the table, the test results show that the correlation coefficient between leadership $\left(\mathrm{X}_{1}\right)$ and performance $(\mathrm{Y})$ is 0.683 which means that there is a moderate or sufficient correlation (correlation) between leadership and performance. The better the leadership of the principal, the better the teacher's performance. The results of the same table show that the correlation coefficient between competence $\left(\mathrm{X}_{2}\right)$ and performance $(\mathrm{Y})$ is 0.566 , which means that there is a moderate or sufficient correlation (correlation) between competence and performance. Or in other words, the better the competence of the principal, the better the teacher's performance. The style of leadership embraced by the Principal would contribute to the results and success of the Principal in guiding and executing the school education process [7].

The findings of the control correlation study indicate that the correlation coefficient between leadership and success is 0.683 . This means that the principal's 
leadership has an effect on teacher results. Although the findings of the determinant coefficient $\mathrm{R}_{2}$ study indicate that the principal's leadership contribution to teacher success is 67.3 percent, the remainder is determined by other factors. The principal's leadership has an impact on teacher results. In multiple linear regression analysis, the coefficient value is constant (constant) of C $=12.649$, while the value of leadership $\mathrm{a}=0.533$ The value of efficiency shows that there is a hypothesis of the effect of principal leadership on performance. Based on the results of the t test, leadership individually affects performance, while the results of the F test also show that leadership affects teacher performance. While the variables $X_{1}$ and $X_{2}$ have their respective parameters. The value of the leadership parameter is 0.533 , where the $t$ test results show that this variable has a significant effect on teacher performance. This means that these variables both separately and together with other variables significantly influence teacher performance. The value of the leadership parameter is 0.533 , where the $t$ test shows that this variable has a significant effect on teacher performance. From the analysis, analysis and $\mathrm{F}$ test and t test, it is found that: Principal leadership has an effect on teacher performance.

The control correlation analysis obtained the test results which showed that the correlation coefficient between competence and performance was 0.566 , which means that there was an effect of the principal's competence on teacher performance. The results of the analysis of the determinant coefficient of $R_{2}$ show that the contribution of competence to teacher performance is $67.3 \%$, the rest is influenced by other factors. This means that there is an influence of the principal's competence on teacher performance. In the multiple linear regression analysis, the coefficient value is constant (constant) of $\mathrm{C}=12.649$, while the competency value of $b=0.544$, the efficiency values indicate that the competence hypothesis has an effect on performance. Based on the results of the $t$ test, competence individually affects performance, while the results of the $\mathrm{F}$ test also show that competence affects teacher performance. While the competency variable $\left(\mathrm{X}_{2}\right)$ has its respective parameters. The competency parameter value is 0.544 , indicating that this variable has a major impact on teacher success according to the $\mathrm{t}$ test results. According to the findings of the study, analysis, $\mathrm{F}$ test, and t test, the principal's competence has an impact on teacher success.

Based on the control correlation study, the test results indicate that the correlation coefficient between leadership and performance is 0.683 , indicating that the principal's leadership has an effect on teacher performance. The test results show that the correlation coefficient between competence and performance is 0.566 , indicating that the principal's competence has an impact on teacher performance. The results of the analysis of the determinant coefficient $\mathrm{R}^{2}$, that the amount of the contribution of the principal's leadership and competence to teacher performance is $67.3 \%$, the rest is influenced by other factors. There is an influence on the leadership and competence of the principal together with teacher performance. In multiple linear regression analysis, the value of the coefficient is constant (constant) of $\mathrm{C}=12.649$, while the value of leadership is $\mathrm{a}=0.533$ and the competency value is $\mathrm{b}=$ 0.544 . The coefficient values indicate that there is a hypothesis that the principal's leadership and competence influence the performance. Based on the results of the $t$ test, leadership and competence individually affect performance, while the results of the $F$ test also show that leadership and competence together affect teacher performance. While the variables $\mathrm{X}_{1}$ and $\mathrm{X}_{2}$ have their respective parameters. The leadership parameter has a value of 0.533 , and the $t$ test results show that this variable has a major impact on teacher efficiency. This means that these variables both separately and together with other variables significantly influence teacher performance. The competency parameter value is 0.544 where the $t$ test shows that this variable has a significant effect on teacher performance. From the results of the analysis, analysis and $\mathrm{F}$ test and $\mathrm{t}$ test, it is found that: Principal leadership and competence together have an effect on teacher performance. Professional teachers have a social obligation that is manifested by the expertise of teachers from the social environment and successful interactive skills [8]. The performance of schools in enhancing learning quality is a collaborative effort between teachers and school principals [9]. The inability of teachers to perform optimally in schools is not entirely due to the teachers' own abilities. Many factors affect teacher performance, both external and internal factors [10].

\section{CONCLUSION}

From the results of the discussion that has been carried out, it can be concluded as follows: 1) the leadership of the principal is quite influential on teacher performance in junior high school education in Air Kumbang District; 2) the competence of the principal is quite influential on teacher performance in junior high school education in Air Kumbang District, and 3) principal leadership and competence affect teacher performance in junior high school education in Air Kumbang District.

\section{ACKNOWLEDGMENT}

Our deepest gratitude goes to Dinas Pendidikan dan Kebudayaan Kabupaten Banyuasin, Chancellor of Palembang PGRI University, Director of the Postgraduate Program of PGRI Palembang University and the Education Management Study Program of PGRI Palembang University, who have supported us in doing this extraordinary thing. This project is funded independently. We also want to thank our Education Management friends who helped us a lot in a short time frame to complete this project. 


\section{REFERENCES}

[1] Simamora, H. (2012). Manajemen Sumber Daya Manusia Ed. 4 [Human Resource Management Ed. 4]. Yogyakarta: STIE YKPN.

[2] Mangkunegara, A. P. (2013). Manajemen Sumber Daya Manusia Perusahaan [Human Resource Management of the Company]. Bandung: PT. Remaja Rosdakarya.

[3] Bernardine, J. H., \& Russel, J. E. (2013). Human Resource Management, Third Edition. New York: McGraw-Hill, Inc.

[4] Robbins S. P., \& Judge. (2011). Perilaku Organisasi [Organizational Behavior]. Buku 2. Jakarta: Salemba

[5] Spencer, M. L., \& Spencer, M. S. (2003). Competence at work Model for Superior. New York: McGraw-Hill, Inc

[6] Hartono. (2005). Manajemen Personalia [Personnel Management]. Yogyakarta: BPEE.

[7] Astuti, R. W., Fitria, H., \& Rohana, R. (2020). The Influence of Leadership Styles and Work Motivation on Teacher's Performance. Journal of Social Work and Science Education, 1(2), 105-114. Retrieved from https://ejournal.karinosseff.org/index.php/jswse/arti cle/view/33

[8] Khasanah, U., Kristiawan, M., \& Tobari. (2019). The Implementation of Principals' Academic Supervision in Improving Teachers' Professionalism in the State Primary Schools. International Journal of Scientific \& Technology Research, 8(8).

[9] Fitria, H., Kristiawan, M., \& Rahmat, N. (2019). Upaya Meningkatkan Kompetensi Guru Melalui Pelatihan Penelitian Tindakan Kelas [Efforts to Improve Teacher Competence through Classroom Action Research Training]. ABDIMAS UNWAHAS, 4(1).

[10] Maryati, E., Fitria, H., \& Rohana, R. (2020). The Influence of Principal's Leadership Style and Organizational Culture on Teacher's Performance. Journal of Social Work and Science Education, 1(2), 127-139. Retrieved from https://ejournal.karinosseff.org/index.php/jswse/arti cle/view/38 